\title{
Corporate Social Responsibility and Its Implementation in Tourism Industry: A Comparative Study between Indonesia and Australia
}

\author{
Anak Agung Bagus Ngurah Agung Surya Putra* \\ Surya Intentilia Education, Bali, Indonesia. \\ Renee Sarah White** \\ Charles Darwin University School of Law, Australia. \\ Kadek Sarna*** \\ Faculty of Law Udayana University, Bali, Indonesia.
}

\begin{abstract}
The concept of Corporate Social Responsibility (CSR) has been widely spread to developing countries. Most scholars argue that the CSR will give economic benefit to the local communities surrounding the company. Indonesia and Australia have adopted the concept of CSR into some legislation and regulations. When the laws of CSR were implemented in the field of tourism, some companies thought that they do not have any legal obligation to implement it. In practice, local communities have used CSR to demand the tourism industries to provide any social, cultural and economic facilities. This article is aimed at providing an analysis regarding the legal framework of Indonesian and Australian laws and regulations concerning CSR, particularly in Tourism Sector. In addition, it is intended to analyze how the implementation of CSR in tourism may strengthen the local communities. It is a normative legal research that primarily scrutinizes written official law and regulations as well as relevant court decisions regarding the issue of CSR, company, and tourism. It can be concluded that both Indonesia and Australia have regulated the concept of CSR very well as stipulated in official law and regulations. Regarding the implementation, by revolving within the scope of sustainable development concept as well as a gradual increase of tourism industries participation in CSR, the well-being of the local community will surely be improved.
\end{abstract}

Keywords: Corporate Social Responsibility; Tourism Industry; Local Communities; Indonesia; Australia.

How to Cite (chicago-16th): Surya Putra, Anak Agung Bagus Ngurah Agung, Renee Sarah White, and Kadek Sarna. "Corporate Social Responsibility and Its Implementation in Tourism Industry: A Comparative Study between Indonesia and Australia." Udayana Journal of Law and Culture 2, no. 2 (2018): 165-190. https://doi.org/110.24843/UJLC.2018.v02.i02.p03.

DOI: https://doi.org/10.24843/UJLC.2018.v02.i02.p03

\footnotetext{
E-mail/Corresponding Author: gunggussurya.surya7@gmail.com

** E-mail: renz_white@hotmail.com

*** E-mail: kadek_sarna@unud.ac.id
} 


\section{Introduction}

\subsection{Background}

Corporate Social Responsibility (CSR) reflects a concept that stimulates companies to maintain and upgrade the condition of communities and the environment surrounding the companies with regard to social and environmental development as well as economic empowerment. The Guidance Standard on Social Responsibility, ISO $26000^{1}$ has conceived it as the responsibility held by organisations in regards to the impacts of decisions and activities on society and the environment.

Through transparent and ethical behaviour companies are expected to address four key issues; to take into account the expectations of stakeholders, implement sustainable development policies which include the health and welfare of society to act in compliance with any legislation and incorporate internationally expected behaviours, and to additionally integrate these policies throughout the entire company. ${ }^{2}$ According to the Triple Bottom Lines (profit, people and planet) ${ }^{3}$ the existence of a company or corporation is not only to gain profit but also benefiting the surroundings. ${ }^{4}$ Bearing in mind those components its connection to the sustainable development in the respective industries of tourism lies in the very core of the establishment of the industries it self.

A lot of Indonesian Limited Liability Companies have actually indicated their efforts in maintaining the well-being of environment and social surrounding through CSR as it is very well regulated in Act of Republic of Indonesia No. 40 Year 2007 concerning Limited Liability Company and further affirmed in Government Regulation No. 47 of 2012 concerning Social and Environmental Responsibility of Limited Liability Company.

In general, the implementation of CSR in Indonesia is not without obstacles. Problems arise from various aspects, ranging from the understanding of such program, familiarising the company with such program, ${ }^{5}$ as well as many other problems that may or may not affect the country of which the company is running. The problem which affects the country thereof is reflected in the corruption case of

1 "ISO 26000 Guidance of Social Responsibility", International Organisation for Standardisation, 2010. http://www.iso.org/iso/home/standards/iso26000.htm.

2 Leeora D. Black, What We Do (29 April 2015) Australian Centre for Corporate Social Responsibility $<$ www.accsr.com.au>.

3 John Elkington is generally known as the expert who coined the term of 'Triple Bottom Lines' in 1994. See http://www.johnelkington.com/archive/TBL-elkington-chapter.pdf

4 See Samuel O. Idowa, Abu Bakar S. Kasum and Asli Yuksel Mermod, People, Planet and Profit: Socio-Economic Perspectives of CSR (Ashgate Publishing Ltd, 2014).

5 In interview with Marketing Manager of Puri Dalem Hotel, I Wayan Artayasa (the Marketing Manager) expressed his lack of understanding of the programme called Corporate Social responsibility, yet the hotel had consistently implemented such social programme in its vicinity. 
prosecutor v. Edy Yuwono et.al. ${ }^{6}$ The problem is a misuse of PT. ANTAMCSR funds by Yuwono, a Rector of the University of Jenderal Soedirman. Even though the problem did not persist in the allocation of CSR funds or the understanding of how the allocated funds should be utilised, this problem should be noted as the hinderance of a smooth implementation of CSR.

It is worth to acknowledge that CSR has approached the tourism sector. Tourism is without questions a vastly growing industry sector in Indonesia and Australia. Industries of tourism in Indonesia have been established in many corners following the national tourism policy that addresses the willingness to create new 10 (ten) promising tourist destination. ${ }^{7}$

We may take Bali Province as an example. The massive development in tourism industries, as indicated by efforts to establish the tourism infrastructures and facilities, has brought great things to the tourism sector in Bali. However, the growth of economic seems only benefiting the side of the industries with less consideration to support the existence of local communities.

The implementation of CSR in Tourism Industries has been inconsistent in Bali since there is no clear ruling enforcing the Industries to implement CSR in the communities that own the village they established the facilities. In fact, a lot of tourism industries are established in the territory of Adat village, the village which consists of local communities based on Adat (customary) Law and particularly on the philosophy of Hindu in Bali. ${ }^{8}$ Even if there are ruling implicitly suggesting tourism industries implement CSR for the wellbeing of local communities, there is no clear concept on how they should implement CSR. Instead of this situation, a progress has been made by Tri Hita Karana (THK) Foundation when in 2017 included a category for a tourism company that implement CSR for an annual award. ${ }^{9}$

In Australia, the issue of CSR become an increasingly relevant topic since its introduction in the early $20^{\text {th }}$ century. ${ }^{10}$ Small to medium-sized enterprises (SMEs) have adopted some CSR elements into their business activities without officially

6 Decision of the Supreme Court of the Republic of Indonesia No. 148/Pid.Sus/2013/PN.Tipikor. Smg. https://putusan.mahkamahagung.go.id/putusan/downloadpdf/5cf008a7f4d29b48b0ae89025fcd3a $65 / \mathrm{pdf}$

7 Liputan 6.Com, "Ini Dia 10 Destinasi Wisata yang Disebut Bali Baru," February 27, 2016, https: / / www.liputan6.com/lifestyle/read/2445931/ini-dia-10-destinasi-wisata-yang-disebut-bali-baru

8 I Made Suasthawa Dharmayuda, Desa Adat Kesatuan Masyarakat Hukum Adat di Propinsi Bali (Denpasar:Upada Sastra, 2001), 3.

9 See further description in Section 2.1.1.5.

10 See Rachael A. Truscott, (2007) Corporate Social Responsibility in Australia: Constructing Reputation. In Proceedings 2007 Australia and New Zealand Marketing Academy Conference (ANZMAC), Dunedin, New Zealand: 2855. 
declaring that they issue a policy. For example, in the field of construction industry, most SMEs have implemented ethical and economic aspects of CSR. ${ }^{11}$

The Australian Centre for Corporate Social Responsibility (ACCSR) was formed over a decade ago to work with organisations be manage impacts and assist in performance reports. ${ }^{12}$ The ACCSR is not limited to the tourism industry, providing assistance to a wide variety of organisations. To define the concept of CSR has externally sourced this information through the International Organisation for Standardization (ISO). The ACCSR have chosen to use this international definition in an attempt to bring clarity to a concept that endures much debate in terms of the definition. These differences can be attributed to several issues; being are a reflection of national and cultural differences in the approach to business practices and differences in disciplinary actions and perspectives on the implementation of CSR methods. Additional to this is the differences in the motivation of organisations to become involved in CSR. Many companies have implemented CSR in the opinion that it is a morally correct practice, in contrast to this it is also common for organisations to use CSR as a makes good business sense. ${ }^{13}$

In Australia, the use of CSR in the tourism industry has become an issue requiring great seriousness and attention. A CSR-like model has been practised since the 1990's as a Non-Government Organisation (NGO) and Australian Tourism Operations Network implemented a certification program to improve tourism industry standards in the tourism industry. The program focuses on social, community and environmental benefits besides including human rights and labour benefits. ${ }^{14}$

\subsection{Purpose}

There are two main legal issues that need to be addressed. First, whether tourism industries have legal obligation to implement CSR in the local communities. Second, regarding the suitable form of CSR programmes to be offered to the local communities that would strengthen their position and role in tourism development. This research is then conducted to assess the legal framework of Indonesian and Australian laws and regulations concerning CSR, particularly in Tourism Sector. In addition, it is aimed at analyzing how the implementation of CSR in tourism may strengthen the local communities.

11 Emma A.M Bevan, and Ping Yung, "Implementation of Corporate Social Responsibility in Australian Construction SMEs," Engineering, Construction and Architectural Management. 22, no. 3 (2015): 295-311, https://doi.org/10.1108/ECAM-05-2014-0071

12 Leeora D. Black, Who We Are (29 April 2015) Australian Centre for Corporate Social Responsibility $<$ www.accsr.com.au>

13 Ibid, 6.

14 See further decription in Section 2.1.2.2 


\subsection{Research Methodology}

It is a normative legal research that basically analyses written official law and regulations and relevant court decisions regarding the issue of CSR, company and tourism. Concept and analysis were very much taken from the textbook, academic journal articles, reports, and website contents. To clarify the facts, some interviews have been conducted by interviewing a legal expert on CSR law and manager of a hotel in Bali. A comparative study was conducted by taking the example of CSR legal framework in the tourism sector in Indonesia and Australia.

This paper deals with two issues in relation to CSR; whether clear rulings are present in legislation and what form of CSR is required to be implemented by the tourism industry to benefit local communities. Each of these issues will be addressed with primary and secondary research and critically analysed. Both issues with will addressed in regard to current research available for Bali and Australia. Each country will be individually analysed and will also be compared to address any similarities implemented by both regions.

\subsection{Literature Review}

CSR is broken down into three issues, this is most commonly known as the 'triple bottom line'; being the environmental, social and economic influences on local communities. The work of Idowa, Kasom and Yuksel Mermod discussed an alternative view of CSR; People, Profit and Planet (PPP) which holds mostly the same ideas as the 'triple bottom line' approach. PPP academics suggest that the focus of CSR is on the plan of approach, where in fact there needs to be more attention given to the end product. ${ }^{15}$ The PPP approach attempts to explain the developmental aspect of CSR from a conceptual perspective with regard to how the delivery of CSR impacts stakeholders (such as employees, customers and government and non-government organisations). ${ }^{16}$ In addition to the bracketed examples of stakeholders, which are considered to be directly impacted stakeholders, there are also the indirectly impacted stakeholders that include, among others indigenous people and local communities. ${ }^{17}$ CSR and PPP have so far allowed for the protection of human rights, response to climate change and addressed the consequences of globalisation. ${ }^{18}$ The term Sustainable Development is also often used in Australian jurisdictions with reference to the Tourism Industry. The definition provided by the World Commission on Environment and Development explains this term as "forms of progress that meet the needs of the present generation without compromising the ability of future generations to meet their needs". ${ }^{19}$

\footnotetext{
15 Samuel O. Idowa, Abu Bakar S. Kasum and Asli Yuksel Mermod, Op.Cit. 2.

16 Ibid.,6.

17 Norms on the Responsibilities of Transnational Corporations and Other Business Enterprises with Regard to Human Rights, U.N. Doc. E/CN.4/Sub.2/2003/12/Rev.2 (2003), para. 22.

18 Samuel O. Idowa, Abu Bakar S. Kasum and Asli Yuksel Mermod, Op.Cit., 1

19 Tourism Australia, What is Sustainability? (2013) <www.tourism-australia.com>
} 
This definition has a similarity with the values of CSR, with the focus of sustainable development being on not only the environmental impacts of tourism but also social and economic. The notion of CSR requires the commitment of companies to conduct their business in an ethical manner while also contributing to economic growth and improving the quality of life for local communities. ${ }^{20}$ As research into the topic becomes more readily available the importance of CSR increases; this is due to the link between economic growth and social and economic well-being is further understood. ${ }^{21}$ Even with the involvement in CSR practices being voluntary and the concept currently not being regulated; companies are under increasing pressure from Government and Non-Government Organisations (NGO) to provide a positive influence on society. ${ }^{22}$

The implementation of PPP and CSR was a topic at the 2010 United Nations Millennium Development Goals (MDG's); 198 words leaders attended the conference in New York to resolve 8 socioeconomic issues. ${ }^{23}$ These issues involved targets such as poverty, education, gender equality, environmental sustainability and the development of sustainable global progress of CSR programs in achieving the required 21 targets. ${ }^{24}$ The United Nations aimed to have made a reduction to poverty rates, improve community health standards (including child mortality, and HIV/AIDS) and promote peace, human rights and gender equality. ${ }^{25}$

The concept of CSR, 'triple bottom line', PPP and sustainable development are all of parallel ideas and goals. The underlying commitment to environmental, social and economic development while attempting to build meaningful relationships within the corporate sector and local communities is a goal that has received growing momentum.

The use of CSR programs is designed the primarily benefit the economic, social and environmental factors of local communities; there also needs to be a benefit to the company to encourage participation. Many tourists are in current times much more aware of the 'footprint' left by companies; choosing a hotel to stay with or airline carrier is often influenced by the sustainability of the business. The implementation of CSR has been found to reduce operating costs, this is achieved through the minimisation of waste, water and energy consumption. ${ }^{26}$ The use of CSR and especially certification in Australian companies will provide a competitive advantage over other businesses as tourists make the conscious decision to support companies choosing to minimise their effect on the PPP. Companies with

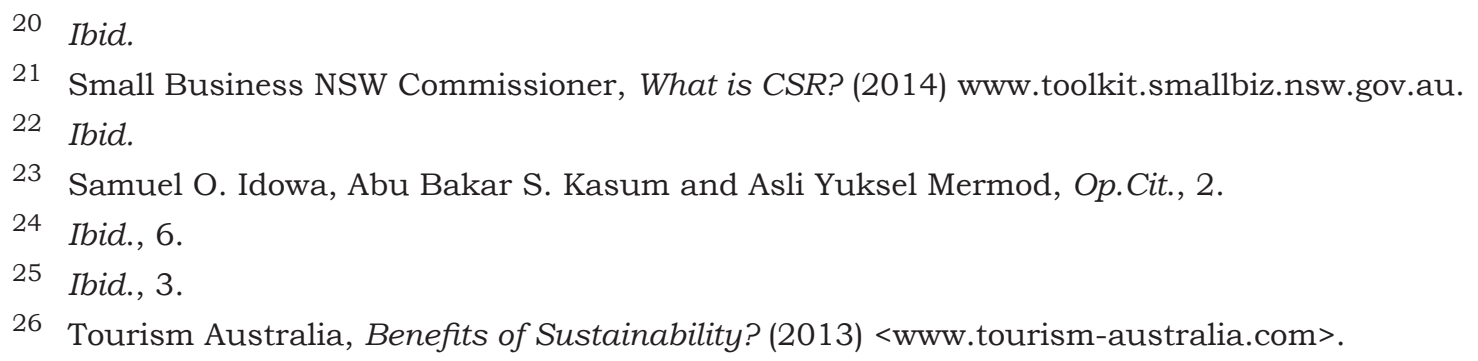


CSR policies are also more likely to attract and retain highly skilled and valuable staff members, this can be attributed to the use of CSR programs that protect the rights of employees to receive fair wages, equal opportunities and gender equality. ${ }^{27}$ Investors in the tourism industry may also be likely to invest in a company where they can show they have sustainable plans for the environment, society and economy. CSR plans have the ability to improve current financial spending along with the future profitability of the company. Upfront expenses, in such areas as transport costs in current time, will create future saving as the price of petroleum continues to rise. $^{28}$ Companies using CSR programs are likely to experience a variety of business improvements, these can be experienced as current benefits to the company and also as long-term improvements.

As with any business concept, there are also debate over the validity of CSR. There is a current debate over where the responsibility of a company lies. One side of this argument sees the responsibility to only extend to those immediately affected by the company such as the owners, directors and shareholders. Alternatively, (and in line with CSR values) others have argued that the responsibility of a company should not be limited. Not only in regards to current environmental, social and economic concerns but also with regard to all past, present and future impacts the company may have on these 'bottom line' issues. ${ }^{29}$ The issue has also been raised that the use of CSR principles undermines the fundamental principles of business practices. Economists believe the true purpose of business is to provide a profitable company, benefiting the owners and shareholders. It is argued that the use of CSR is a conflict to the fundamental purpose of business practices. ${ }^{30}$

As ruled in Dodge $v$. Ford,$^{31}$ the primary purpose of the business organisation is to gain profit for the stakeholders. ${ }^{32}$ This seems to be very straightforward to the extent of a business organisation to exist in the first place, notwithstanding the jarring ruling, this case is not unique. In the traditional approach of CSR, the business company has no place for charity in its board of directors, thus making a CSR is rather unimportant if it has no benefit to the company. ${ }^{33}$

Minh Nguyen, Jo Bensemann, and Stephen Kelly developed a multilevel conceptual framework to understand the CSR nature in Vietnam that consisting

27 Human Rights Commission, Corporate Social Responsibility and Human Rights (2008) <www.humanrights.gov.au>.

28 Tourism Australia, Benefits of Sustainability? Op.Cit.

29 Small Business NSW Commissioner, Op.Cit.

30 Ibid.,49.

31 Dodge v. Ford Motor Co., 204 Mich. 459, 170 N.W. 668, 1919 Mich. LEXIS 720, 3 A.L.R. 413 (Mich. 1919).

32 Ibid., 684 per Ostrander CJ, 685 per Steere, Fellows, Stone, Brooke JJ concurring

33 David Greenberg, "Making Corporate Social Responsibility anEveryday Part of the Business of Business: OfferingRealistic Options for Regulatory Reform,” Bond Law Review 19, no. 2 (2007): 43. 
of three institutional contextual factors, namely tradition, political governance, and modernity. ${ }^{34}$ In an understanding that CSR concept is not well defined in Vietnam and that western frameworks may not hold up in the Vietnamese context, They argued that any examination of CSR in Vietnam without contextualisation could perpetuate a superficial understanding of CSR and may yield invalid results. ${ }^{35}$

International communities have enriched the basic idea of CSR by endorsing a concept of corporate responsibility under the human rights framework. It has been emphasized, as a foundational principle, that business enterprises should respect human rights. ${ }^{36}$

It is important to consider that as knowledge grows into sustainable development of the environment, society and the economy companies are likely to see a merge in values. Public opinion is a very important tool while trying to run an effective business if companies hold to these out-dated opinions of fundamental business practices they will likely lose their competitiveness in the tourism industry.

Some studies have elaborated on the issue of CSR. Laurensia Andrin conducted a study on CSR that analyses how mandatory CSR is for limited liability company having business in the field of and/or related to natural resources and why CSR needs to be mandatory instead of voluntary. ${ }^{37}$ She views Indonesian government has a mediocre stance in regulating CSR. ${ }^{38}$ One hand, the government has the intention to create social and environmental obligation towards companies having business related to the utilization of natural resources, while on the other hand, it seems to leave the company obligations without any specific regulation on how the CSR should be implemented by the company. ${ }^{39}$

Muchamad Ali Safa'at discusses CSR from a constitutional law perspective, especially human rights aspect. ${ }^{40}$ He argued that from a Constitutional Law Perspective the development of CSR regulation has a very solid foundation, at least for four reasons. First of all, CSR is one of the efforts to achieve social Justices as one of the bases of the state. Second, CSR is a form of corporate constitutional obligation to respect and promote human rights. Third, CSR mandatory regulation

34 Minh Nguyen, Jo Bensemann, and Stephen Kelly, "Corporate Social Responsibility (CSR) in Vietnam: a Conceptual Framework," International Journal of Corporate Social Responsibility 3, no.9 (2018): 1, https://doi.org/10.1186/s40991-018-0032-5

35 Ibid, 10.

36 The Office of the UN High Commissioner for Human Rights, Guiding Principles on Business and Human Rights Implementing the United Nations "Protect, Respect and Remedy" Framework, United Nations, 2011: 13.

37 The Office of the UN High Commissioner for Human Rights, Guiding Principles on Business and

38 Ibid, 514.

39 Ibid.

40 Muchamad Ali Safa'at, “Corporate Social Responsibility: A Constitutional Perspective," Jurnal Konstitusi 11, no. 1 (March 2014): 3. 
can be justified because the state holds the primary responsibility for the protection and fulfilment of human rights, including establishing a rule that imposes a CSR duty to the corporation. Fourth, there is a potential violation of civil and political rights as well as economic, social, and cultural rights as guaranteed by the Indonesian Constitution that requires company to play a role in the protection and promotion of human rights. ${ }^{41}$

An emerging discussing raises when CSR is implemented in the tourism sector. Tourism and its impact on the social environment are commonly discussed among scholarly articles. The discussion ranging from its impact as a worldwide phenomenon that has become one of the faster-growing sectors of the global economy, to its direct and indirect exploitation of the culture of the society in general and the indigenous one. ${ }^{42}$ Relying on this, it is reasonable to assume that tourism industry owes a significant amount to its surroundings especially to those living in the vicinity of the tourism industry. ${ }^{43}$

Scholars also think that this particular sector is an effective stimulant to the economy of a country or a region and it is not a news, especially in Indonesia. ${ }^{44}$ Tourism itself is defined as any activities involving tourists as the centre of things, ${ }^{45}$ which typically produce tourism characteristic products. ${ }^{46}$ The said products involve either good or services that represent the supply and demand of the tourism that would cease to exist upon the absence of visitors. ${ }^{47}$

There has been some literature discussing CSR in tourism. Hughes and Scheyvens conducted a study in order to respond to the greater demands on businesses after 2015 by proposing a Development First framework for CSR that

41 Ibid, 16.

42 See Azilah Kasim, "The Need for Business Envronmental and Social Responsibility in the Tourism Industry," International Journal of Hospitality \& Tourism Administration, 7 no. (2016): 1-22, DOI: 10.1300/J149v07n01_01 (2006); See also Putri Triari Dwijayanti et al, "Indigenous People, Economic Development and Sustainable Tourism: A Comparative Analysis between Bali, Indonesia and Australia," Udayana Journal of Law and Culture 1,no. 1 (2017): 16-30.

43 Tjok Istri Putra Astiti and I Ketut Sudantra, "Reflecting on Tourism Activities in Bali: A Discourse on Communal Rights, Culture and Hindu Values," in Sustainable Tourism and Law, ed. Michael G. Faure, Ni Ketut Supasti Dharmawan and I Made Budi Arsika (Den Haag: Eleven International Publishing, 2014), 235.

44 Made Suksma Prijandhini Devi Salain, David Isles, and I Gusti Ngurah Wairocana, "Regulating Indigenous Culture as A Tourism Economic Resource," Udayana Journal of Law and Culture 1 (2): 121140. doi:10.24843/UJLC.2017.v01.i02 (2017): 3; See also Aditya Yuli, "City Branding Sebagai Strategi Pengembangan Pariwisata Ditinjau dari Aspek Hukum Merek (Studi Kasus City Branding Daerah Istimewa Yogyakarta sebagai Daerah Tujuan Wisata Unggulan di Indonesia)", Jurnal Ilmiah Ilmu Hukum QISTI 5, no. 1 (2011).

45 John Tribe, "The Concept of Tourism: Framing a Wide Tourism World and Broad Tourism Society", Tourism Recreation Research 24, no.2 (2014): 75-81. https://doi.org/10.1080/02508281.1999.1 1014879

46 "Understanding Tourism Basic Glossary," World Tourism Organisation URL: cf.cdn.unwto.org/ sites/all/files/docpdf/glossaryenrev.pdf

47 Ibid. 
is adapted from Peter Burns' tourism planning model. ${ }^{48}$ Another publication can be read in a qualitative research conducted by Patricia Martinez et.al that develops an efficient measurement scale for CSR in the tourism industry. Such research discovered a multidimensional structure including economic, social, and environmental issues. ${ }^{49}$

Mara Del Baldo published an article that aims to analyse the fundamentals (internal and external factors) which characterize the sustainable business model in the tourism sector that is conducted in both deductive and inductive research approach. ${ }^{50}$ On the issue of governance and transparency, he discussed that the company is aware that the consolidation of a clear positioning as responsible company necessarily requires a strengthening of disclosure processes which rests on a gradual and lengthy evolution of the company culture. In particular, the monitoring of economic, financial, social and environmental objectives presupposes a reliable business reporting capable of stimulating information sharing and collaboration with stakeholders. ${ }^{51}$

\section{Result and Analysis}

\subsection{Legal Framework on Corporate Social Responsibility in Tourism Sector}

\subsubsection{Case Study of Indonesia}

The following explanations will describe the regulation of CSR under the Indonesian Investment Act, Indonesian Limited Liability Company Act and its Implementing Regulation, the decision of Indonesian Constitutional Court concerning CSR issue. In addition, this section will also discuss the legal framework on CSR in tourism in Indonesia.

\subsubsection{Indonesian Investment Act}

ActNo. 25 Year 2007 concerning Investment stipulates that every investor is obliged to implement CSR. ${ }^{52}$ What is meant by CSR is the responsibility inherent in each investment firm to keep creating relationships harmonious, balanced, and in accordance with the environment, values, norms, and local culture. ${ }^{53}$ While the

48 Emma Hughes and Regina Scheyvens, "Corporate Social Responsibility in Tourism Post-2015: A Development First Approach," Tourism Geographies 18 no.5 (2016): 469-482. https://doi.org/10.1080/14 616688.2016.1208678

49 Patricia Martinez, Andrea Pérez and Ignacio Rodríguez del Bosque, "Measuring Corporate Social Responsibility in Tourism: Development and Validation of an Efficient Measurement Scale in the Hospitality Industry," Journal of Travel \& Tourism Marketing 30, no.4 (2013): 365-385. https:// doi.org/ 10.1080/1054 8408.2013.784154

50 Mara Del Baldo, "Sustainability and CSR Orientation through "Edutainment" in Tourism," International Journal of Corporate Social Responsibility 3, no.5 (2018):1, https://doi.org/ 10.1186/s40991018-0027-2

51 Ibid, 8.

52 Act of Republic of Indonesia No. 25 Year 2007 concerning Investment, Art. 15 (b).

53 Act of Republic of Indonesia No. 25 of 2007 concerning Investment; see also Md. Abdul Hamid, 2010, “CSR in Tourism", SSRN available at: http://dx.doi.org/10.2139/ssrn.1684185 
definition of investor is an individual or business entity that makes an investment that can be either domestic investors or foreign investors. ${ }^{54}$ In addition, Article 16 stipulates that every investor is responsible to preserve the environment.

\subsubsection{Indonesian Limited Liability Company Act}

Corporate Social Responsibility in Indonesia is regulated under the Act No. 40 Year 2007 concerning Limited Liability Company. This Act defines social and environmental responsibility as a commitment of companies to actively involved in sustainable economic development in order to develop the quality of life and the environment in which has benefit the companies, local communities as well as the community in general..$^{55}$

Article 74 (1) of this Act, in essence, regulates that Limited Liability Company (LLC) which run their business in the field of or related to the natural resources are obliged to implement social and environmental responsibility. Article 74 (3) further emphasizes that the non-compliance of such rule may be imposed a sanction. ${ }^{56}$ However, elucidation of this provision does not give an explanation on what kind of sanction shall be given to the company, ${ }^{57}$

\subsubsection{Government Regulation concerning Social and Environmental Re- sponsibility of Limited Company}

It is further affirmed in the Government Regulation No. 47 Year 2012 concerning Social and Environmental Responsibility of Limited Liability Company that the LLC has obligation to implement CSR. ${ }^{58}$ The implementation of CSR is carried out by the Director in accordance with the annual work plan of the Company after consented by the Board of Commissioners or the General Meeting of the Shareholders in accordance with the Charter of the Company. ${ }^{59}$ This regulation reiterates the norm as stipulated in Article 74 (3) of the Indonesian Limited Liability Company Act that the disobedience in implementing CSR may be imposed a sanction, ${ }^{60}$ but, again, does not further explain in detail the type of sanction.

Local governments have interpreted that the suitable type of penalty to be imposed on companies that are not implemented CSR is an administrative sanction. This may be in form of written warning, restrictions on corporate activities, freezing of

\footnotetext{
54 Act of Republic of Indonesia No. 25 Year 2007 concerning Investment, Art. 1 (4).

55 Act of Republic of Indonesia No. 40 Year 2007 concerning Limited Liability Company, Art.1 (3).

56 Ibid, Art. 74 (3).

57 Ibid. See Elucidation Art. 74 (3).

58 Government Regulation of Republic of Indonesia No. 47 Year 2012 concerning Social and Environmental Responsibility of Limited Liability Company, Art. 3 (1).

59 Ibid, Art. 4 (1).

60 Ibid, Art. 7.
} 
Corporate Social Responsibility and Its Implementation in Tourism Industry: A Comparative Study between Indonesia and Australia Anak Agung Bagus Ngurah Agung Surya Putra, Renee Sarah White, and Kadek Sarna

business activities and/or investment facilities, and revocation of business licence and/or investment facility. ${ }^{61}$

\subsubsection{The Ruling of Indonesian Constitutional Court on CSR: Strengthening the Obligatory Character of CSR}

A judicial review regarding the constitutionality of rule on CSR was submitted by Muhammad Suleiman Hidayat (Chief of Indonesian Chamber of Commerce and Industry) et.al before the Constitutional Court of Indonesia. ${ }^{62}$ The applicants requested the Court to examine the constitutionality of Article 74 of Act No. 40 Year 2007 concerning Company. They argued that this provision violates constitutional rights on legal certainty as stipulated in Article 28D (1) of, implies a discriminatory character that against the norm laid down in Article 28I (2) Indonesian Constitution, and does not reflect the principle of fair efficiency as underlined in Article 33 (4) of Indonesian Constitution. ${ }^{63}$

The Court taken into consideration of statement submitted by an expert Maria R. Nindita Radyati that explains the CSR should be meant in line with culture developed in each country and therefore the implementation of CSR in Indonesia is different from the practice in the United Kingdom, Australia, the Netherlands, Canada, France, Germany, and the United States of America. ${ }^{64}$

On the issue of interpretation on double charges imposed to the company, The Court clarifies that there is a clear difference between taxation and CSR and therefore the two type of funds cannot be generalized. ${ }^{65}$ One hand, tax is used for national development while on the other hand the fund of CSR is utilized for the sake of communities and environmental recovery surrounding the company. ${ }^{66}$ This hence makes clear that there will be no double charges because the cost incurred for CSR will be calculated as the cost of the company in which its implementation is constituted by the ability of a company. ${ }^{67}$

The Court also considers that constructing CSR as a legal obligation, instead of classifying CSR as a voluntary nature, would make it having more legal certainty. The Court had an expectation that the shifting from voluntary into mandatory character

61 Regulation of Buleleng Regency No. 7 Year 2017 concerning Corporate Social and Environment Responsibility, Art. 25 (1) and Regulation of Badung Regency No. 7 Year 2017 concerning Corporate Social Responsibility, Art. 22.

62 Decision of Constitutional Court of the Republic of Indonesia No. 53/PUU-VI/2008, Para 1.2, 1, http://www.mahkamahkonstitusi.go.id/public/content/persidangan/putusan/putusan_sidang_Putusan\%20Nomor\%2053\%20PUU\%20VI2008.pdf

63 Ibid. Para 2.1. 3.

64 Ibid. Para 3.19. 92.

65 Ibid.

66 Ibid.

67 Ibid, 93. 
would ensure the company contributions to participate in improving the welfare of society. In addition, the legal obligation of CSR would anticipate various interpretation by companies to implement it. ${ }^{68}$

In the Verdict, the Court decided that the norms and legal obligation of CSR as stipulated in Articles 74 (1), (2), and (3) and elucidation of the Act No. 40 Year 2007 on Company is not incompatible with Articles 28D (1), 28I (2), and 33 (4) of the 1945 Constitution of the Republic of Indonesia. ${ }^{69}$

The judgment was not adopted unanimously. Three among nine Justices of the Indonesian Constitutional Court deliver a joint dissenting opinion. They paid an attention to the term "should" in the seven principles of CSR as stipulated ed in ISO 26000 and concluded that the implementation of CSR has a voluntary character as it is very much linked to the issue of ethics, moral, and appropriateness. ${ }^{70}$ They are in an opinion that the principle of togetherness must be upheld in a trusted and egalite relations between government and entrepreneurs, so thus, the implementation of CSR should not be a legal obligation under the Law and should not be punishable in case of non-compliance. ${ }^{71}$ Both obligation and sanction natures in the rules on CSR implies that the State has a more dominant position on the entrepreneur, so the principle of togetherness is not respected anymore. ${ }^{72}$

Muchammad Ali Safa'at assesses the legal reasoning in the decision of the Court. He views that mandatory CSR regulation is based on the basic constitutional principle of social justice, control of the State over natural resources, and the principle of people-oriented economy. ${ }^{73} \mathrm{He}$ also criticizes the judgment that has not considered the constitutional provisions on human rights that is in contrast to the international developments on the concept of CSR that very much adopt human rights approach. Despite Indonesian Constitutional Court rejected this judicial review, the debates on whether the CSR shall be mandatory or voluntary in nature still goes on. ${ }^{74}$

\subsubsection{CSR in Tourism in Indonesia}

If we take a closer look at the clause "in the field of natural resources"75 we would immediately think of Industries of gas, oil, mining or any other companies that directly use the natural resources. Tourism Industries would be discounted from that clause. The clause "related to natural resources", in the other hand, gives

\footnotetext{
68 Ibid.

69 Ibid, Para 4.5.

70 Ibid. Joint dissenting opinions by Justices Maria Farida Indrati, Maruarar Siahaan, and M. Arsyad Sanusi, Para 6, 103-104.

71 Ibid, 110.

72 Ibid.

73 Muchamad Ali Safa'at, Op.Cit., 6.

74 Laurensia Andrin, Op.Cit., 513.

75 As written in Act No. 40 of 2007.
} 
the obligation of CSR to the company that do not use natural resources but the establishment affect the natural resources, which means tourism industries are included. ${ }^{76}$

According to Article 1 paragraph 9 of Act No. 10 Year 2009 concerning Tourism, the industries of tourism are integrated associations of tourism business in order to provide goods and/or services to satisfy the needs of tourism in conducting the tourism. Article 7 then stipulates that the development of Tourism includes:
a. Tourism industries
b. Tourism destination
c. Marketing
d. Tourism institution

The Law then explain that the development of tourism industries is the development of structure (function, hierarchy and relation) of the industries, competitiveness, a partnership of tourism business, the credibility of the business, as well as the responsibility with regard to the environment and social culture. ${ }^{77}$

It is worth to acknowledge that some local governments that very much benefited from tourism industry have approaching regulations on CSR to tourism industry. For example, Government of Badung regency enacted Regulation No. 6 Year 2013 concerning Corporate Social Responsibility that does not explicitly mention CSR shall be applied in the tourism sector. As stipulated in Article 10 of this regulation, every company in the region of Badung, without clarifying the type of company activities, must implement CSR. The concern CSR in tourism sector can be seen in Elucidation of this Act that explains the rapid growth of the current economy can be indicated from the increasing number of company types that grow and develop, among others, hotels, transport services, and other tourism support services. ${ }^{78}$ It also further explains that this regulation was enacted by considering that Badung region has a strategy to manage the CSR in the region in order to ensure that CSR will be implemented in harmony in accordance with Balinese culture, inspired by Hindu values, related to socio-economic aspects and ecosystem as supporter of cultural tourism talent. The aforementioned explanation indicates that rules covering the issue of CSR in tourism are implied in local regulation.

CSR in the tourism sector has been practised in Bali. The direct and indirect impacts of tourism cause the LLCs engaged in tourism have an obligation to

76 Anak Agung Sri Indrawati, Ni Ketut Supasti Dharmawan, and Ida Ayu Sukihana, "Implelmentasi Konsep CSR (Corporate Social Responsibility) Pada Perusahaan Industri Pariwisata di Bali," Jurnal lmiah Fakultas Hukum, Udayana University (2012): 131; see also Antonio Argandoña, "Corporate Social Responsibility in the Tourism Industry: Some Lessons from the Spanish Experience," IESE Business School Working Paper No. 844 (2010): 14. Available at SSRN: http://dx.doi.org/ 10.2139/ssrn.1593592

77 Explanation to Article 7 of Law No 10 Year 2009 concerning Tourism.

78 Regulation of Badung Regency No. 6 Year 2013 concerning Corporate Social Responsibility, Elucidation, Part. I. 
implement CSR. These companies may implement CSR by conducting environmental management and social activities for the local communities that support the sustainable tourism development in Bali. ${ }^{79}$ We may also take an example of Tri Hita Karana (THK) Foundation that regularly conducts annual award to tourism stakeholders that implement the principles of Tri Hita Karana (the three causes of well-being). ${ }^{80}$ In 2017, the THK Award included a category for tourism company that implement CSR. ${ }^{81}$ One of the tourism companies that have been awarded CSR THK Award 2017 is Indonesia Tourism Development Corporation (ITDC), a State-own Enterprises due to its effort to develop an initiation project of Pinge Tourism Village, a village that is located in Tabanan regency. Such CSR award stimulates ITDC to develops some tourism villages in the northern part of Bali in 2018.82 A few years ago, tourism industries that are located in Gianyar regency provided a medical check for the eye as well as surgery for cataract. ${ }^{83}$ Moving to the southern part of Bali, Melia Hotel, one of hotels located in Nusa Dua, did its CSR programme by celebrating Universal Children Day. ${ }^{84}$

In an interview with Ni Ketut Supasti Dharmawan, she expressed her joy at seeing how well tourism industries have committed to implementing the CSR programme.$^{85}$ Her words are affirmed by the practice of Bali Safari and Marine Park which did the programme of CSR by playing a role for public health.

\subsubsection{Case Study of Australia}

Both the Australian government and corporations involved in making progress of CSR. In last decade, some government initiatives on CSR can be seen in Prime Minister's Business Community Partnership awards, Australian Government Corporations and Markets Advisory Committee, Parliamentary Joint Committee on Corporations and Financial Services and related reports commissioned by Department of Family and Department of the Environment and Heritage. ${ }^{86}$ The progress made

79 Viddi Dandi Yanta, "Implementasi Corporate Social Responsibility (CSR) Pada Perseroan Terbatas yang Bergerak dalam Bidang Pariwisata di Bali” (Thesis, Magister of Notary, Gadjah Mada University, 2009).

80 See Dik Roth and Gede Sedana "Reframing Tri Hita Karana: From 'Balinese Culture' to Politics", The Asia Pacific Journal of Anthropology 16, no. 2(2015) 157-175, DOI: 10.1080/14442213.2014.994674

81 “Tri Hita Karana CSR Awards Bagi Perusahaan yang Melakukan Tanggung Jawab Sosial," Kabar Dewata, November 27, http://kabardewata.com/berita/berita-utama/sosial/tri-hita-karana-csr-awardsbagi-perusahaan.html\#.WxVKHzSFNdg2017.

82 Ema Sukarelawanto, "ITDC Raih Super Platinum \& CSR Tri Hita Karana Award 2017," Kabar 24-Bisnis.Com, November 26, 2017, http://kabar24.bisnis.com/read/20171126/78/712684/itdc-raihsuper-platinum-csr-tri-hita-karana-award-2017

83 Bali Safari and Marine Park, Safari Peduli Pemeriksaan Mata dan Operasi Katarak untuk Lansia bersama John Fawcett Foundation<http://www.balisafarimarinepark.com/news/1395/safari_peduli_pemeriksaan_mata_dan_operasi_katarak_untuk_lansia_bersama_john_fawcett_foundation_.html>

84 CSR Bali, Universal Children Day Celebration at Melia Bali Indonesia. < http://www.csrbali.com/ universal-children-day-celebration-at-melia-bali-indonesia.htm>

85 Ni Ketut Supasti Dharmawan, "CSR in Tourism Industries, " interview by Authors, Faculty of Law, Udayana University, Denpasar, December 7, 2015.

86 Rachael A. Truscott, Op.Cit, 2857. 
by the government was hand in hand with business sectors initiatives. Structure of companies have accommodatedCSR positions, departments and committees besides seeking expert advice on CSR strategy development from niche CSR consultancies. In addition, conferences and events have regularly convened in Australia discussing thematic issues and involving the wide range of interested actors. ${ }^{87}$

\subsubsection{Australian Corporation}

The Corporations Act 2001 (Cth) in Section 181(1) subsection A states a director (or another officer) of a corporation must "exercise their powers and discharge their duties" 88 while acting in good faith and in the best interest of the corporation. Subsection (b) states the director must act in relation to a proper purpose. This provides several issues; the interpretation of 'good faith' and 'proper purposes' and the lack of inclusion for the best interests of the community. The Act does not define these specific terms ${ }^{89}$; additionally, the Acts Interpretation Act 1901 (Cth) also does not provide for these terms. ${ }^{90}$ It is then adequate to use the natural meaning of the word (or phrase); the term good faith is defined as the "honesty of purpose or sincerity of declaration". ${ }^{91}$ In interpreting this it is it is important to consider the purpose of the Corporations Act 2001 (Cth); this being that the Act is not limiting the operation of State or Territory law and is intended to impose additional obligations, liabilities and powers on organisations. ${ }^{92}$

Therefore, it is adequate to assume the Act is suggesting in section 181 that an organisation is required to perform its business obligations in an honest and sincerer manner. The Act fails to specifically mention the need to act in the best interests of the local communities (or environment). Subsection (b) referring to the director of an organisation acting for 'proper purposes' is also a section that can be misinterpreted. This is quite an open phrase, giving organisations a wide scope while acting within the law.

\subsubsection{CSR in Tourism in Australia}

Since the 1990's Australia has implemented a certification program to achieve improvement of standards in the tourism industry. This is offered through the Nature and Ecotourism Accreditation Program (NEAP) which provides voluntary accreditation for organisations. This program is offered by a Non-Government Organisation (NGO) in conjunction with the Australian Tourism Operations Network. ${ }^{93}$

\footnotetext{
87 Ibid.

88 Corporations Act $2001 \mathrm{~S} 181$.

89 Corporations Act 2001 (Cth) s9.

90 Acts Interpretation Act 1901 (Cth) Part 2.

91 Macquarie Online Dictionary (2015) <www.macquariedictionary.com.au>.

92 Corporations Act 2001 (Cth) S5E.

93 Rachel Dodds and Marion Joppe, CSR in the Tourism Industry? The Status of and Potential for Certification, Codes of Conduct and Guidelines (2005), 50.
} 
The focus is on social, community and environmental benefits while also incorporating human rights and labour benefits. The program is currently funded by involved companies with incentives for businesses involving cost saving and the marketing sectors. ${ }^{94}$ Random audit checks are carried out by an accredited agency; well-defined criteria is set out along with the use of third-party auditors to provide reliable accreditation. ${ }^{95}$

The purpose of providing certification for companies is to assure customers and the Tourism Industry that the company has achieved a minimum set of standards; additionally, this also provides benefits to the local community and environment. ${ }^{96}$ As the use of certification grows competing organisations will find themselves in a position requiring them to also meet these base guidelines to become effectively competitive.

\subsubsection{Current Practices}

Unlike practices in Indonesia, where CSR is an obligation burdened to companies, Australia has different takes on how should CSR be implemented. CSR can also be seen as an emerging industry seeking legitimacy and relying on reputation in order to grow and survive. ${ }^{97}$

In a report issued by the Business Events Australia, Tourism Australia in November 2010 it was reported that since the previous Audit in 2008 participation was rising. In 2010 it was reported that 36\% of organisations (of 347 surveyed) hold at least 1 accreditation for social or environmental responses to CSR. This figure in 2008 was reported as $31 \%$, showing an increase of $5 \% .{ }^{98}$ Australian convention and exhibition Centres audited reported a $75 \%$ accreditation rate; the travel industry reported a $56 \%$ accreditation rate with the accommodation organisations reporting at $47 \%$. Both the types of organisations have seen an improvement with the 2008 report finding $46 \%$ of transport organisations hold an accreditation and $39 \%$ of accommodation organisations..$^{99}$

Australia has made great progress over the last few decades with the growth of organisations voluntarily becoming certified under the NEAP. The formation of the ACCSR has brought CSR to the forefront in many business sectors. The Tourism Industry is one of many that have now started considering the impacts day to day operations have on local communities in regards to social, economic and environmental factors. Regardless of this improvement without clarification within legislation, the 
issue of CSR will possibly reach a standstill in development. Amending relevant legislation will provide all businesses in the Tourism Industry with a minimum baseline to work from and will ensure the protection of social, economic and environmental factors in the local communities. The continued use of voluntary certification under NEAP and assistance provided by ACCSR will assist regulate CSR while the introduction of CSR into legislation with protecting the human rights of the local communities. Additional to the inclusion of CSR into legislation is the need to allocate the power to monitor the implementation of CSR; the decision to form a new agency dedicated to ensuring organisations fulfil their legislative requirements is the most likely option.

\subsection{Does CSR in Tourism Strengthen the Local Communities?}

\subsubsection{The Concern of International Community: The Role of UNWTO to Promote CSR in Tourism Sector}

International society has an awareness that global tourism should pay an attention to the host communities of the tourism industry. The United Nations World Tourism Organization (UNWTO) has established a Global Code of Ethics for Tourism that guides "local populations should be associated with tourism activities and share equitably in the economic, social and cultural benefits they generate..."100 In addition, this Code emphasizes that "Tourism policies should be applied in such a way as to help to raise the standard of living of the populations of the regions visited and meet their needs"101.

The UNWTO also created some initiatives in addressing the negative impacts of business through a voluntary commitment to CSR. In 2011 the UNWTO Secretariat started a campaign geared towards the private sector by inviting tourism enterprises and their trade associations to adhere to the Private Sector Commitment to the Global Code of Ethics for Tourism. ${ }^{102}$ In signing the commitment, companies pledge to uphold, promote and implement the values of responsible and sustainable tourism development championed by the Code. A special focus on social, cultural and economic matters is one of the main objectives of the Commitment, which draws particular attention to issues such as human rights, social inclusion, gender equality, accessibility, and the protection of vulnerable groups and host communities. As of April 2018, 553 companies and associations from around the world have signed the Private Sector Commitment to the Code of Ethics. ${ }^{103}$

\footnotetext{
100 Global Code of Ethics for Tourism, Art. 5 (1).

101 Ibid, Art. 5 (2).

102 United Nations World Tourism Organization, “Corporate Social Responsibility Initiatives,"http:// ethics.unwto.org/content/corporate-social-responsibility-initiatives

103 "United Nations World Tourism Organization, "Private Sector Commitment to the UNWTO Global Code of Ethics for Tourism,"http://ethics.unwto.org/content/private-sector-commitment-unwto-globalcode-ethics-tourism
} 


\subsubsection{Case Study of Indonesia}

Local Community is acknowledged in Indonesia along with their traditional customary rights as long as it is in accordance with the societal development and the principles of the Republic of Indonesia. ${ }^{104}$ It is further affirmed in Article 28I (3) which stipulates, "The cultural identities and rights of traditional communities shall be respected in accordance with the development of times and civilisations".

In the Laws of CSR, though not generally ruled, local communities' rights are ensured in the Article 11 (3) (p) of the Act No. 22 Year 2001 concerning Oil and Natural Gas which in essence stipulates that companies in their joint contracts need to include the assurance of the development of communities especially local communities.

In addition to that ruling, Local Government of Badung, Bali, through Regulation of Head of Badung Regency No. 6 of 2011 concerning CSR, particularly Article 11, stipulates that one of the forms of CSR is Communities Empowerment. Even though this regulation does not specifically state local communities it is reasonable to include or the right of local communities is implied within the abovementioned ruling.

\subsubsection{Case Study of Australia}

The Australian Human Rights Commission is invested in the use of CSR by corporations to ensure individuals' basic human rights are not violated. Local communities should be extended the right to enjoy life without being influenced by large organisations. Companies often fail to connect the importance of private decisions on public welfare. ${ }^{105}$ The 'triple bottom line' approach incorporates economic, social and environmental implications into the one concept. It is important for company directors to understand that the importance of societies values and interests must be given importance over those of their own. ${ }^{106}$ Each of these approaches is relevant in the use of CSR and Human Rights; this is evident in Labour Rights and the expectation of organisations to pay fair wages to employees; Human Rights and the right to non-discrimination and the human rights to have access to clean drinking water. ${ }^{107}$

These examples illustrate how fundamental human rights as expressed in the Commonwealth of Australian Constitution Act 1901 (Cth) and Australian Human Rights Commission Act 1986 are incorporated into the implementation of CSR. Organisations neglecting to operate business practices with regards to CSR policies are likely to impede on the basic Human Rights of Australian citizens. Quality of life

104 The 1945 Constitution of the Republic of Indonesia, Art.18B (2).

105 Howard R. Bowen, Jean-Pascal Gond, Peter Geoffrey Bowen, Social Responsibilities of the Businessman (University of Iowa Press, 2013). 4.

106 Ibid.

107 Human Rights Commission, Corporate Social Responsibility and Human Rights (2008) <www. humanrights.gov.au>. 
and satisfaction of life is likely to decline as a result of companies failing to implement CSR policies.

Tourism industries, as in the last chapter, have done several notable CSR programmes. However, when it comes to the implementation to the local communities it needs more than just a financial support, as most companies in Indonesia think these days. This does not say that financial support is not needed.

In an interview with the accounting manager and human resource manager of Puri Dalem Hotel, CSR is not implemented just to gain existence as most tourism industries would normally do. They do not even know what CSR is but they have done notable social programmes. One of the programmes they most proud of is managing the human resources of local communities in East Sanur. ${ }^{108}$ There is no clear definition of managing the human resources, however as practices shown what it does to the human resources is to have them go through a process which consists of planning, organising, leading and controlling. ${ }^{109}$

\section{Conclusion and Recommendation}

\subsection{Conclusion}

Corporate Social Responsibility (CSR) has been very well regulated under the law and regulation in both Indonesia and Australia. In Indonesia, the concept of CSR has been transformed into norms as stipulated in Limited Liability Act, Investment Act, and some regulations issued by central and local governments while in Australia the CSR has basically been incorporated into Corporation Act, and to some extent, Commonwealth of Australian Constitution Act and Australian Human Rights Commission Act. The main differences are that Indonesia as the developing country still needs to apply the concept of CSR mandatorily through obligation owed in written Laws and regulations. On the other hand, Australian relies solely on the commitment of the companies to contribute to the development of their surroundings. With regard to the implementation by tourism industries, both countries seem to do well in implementing this concept. With a gradually increasing number of tourism industries take part in realising the sustainable development, the well-being of local communities surrounding the field of the company will surely be improved. Its implementation to local communities should never be away from the basic concept of sustainable development. People, profit and planet should be kept in balance, otherwise, it could have a bad impact not only to the business but also to the local communities, the communities surrounding them as well as the environment. Gaining just an image is not encouraged in sustainable development as companies are needed to show their commitment to applying the CSR programme not just financially but also in developing the human resources.

108 Artayasa, Wayan, "CSR: Implementation," interview by Authors, Puri Dalem Hotel, Sanur. December 8, 2015.

109 I Gusti Ngurah Gorda, Manajemen Sumber Daya Manusia (Astabrata Bali in Cooperation with STIE Satya Dharma, 2004), 12. 


\subsection{Recomendation}

Local communities that receive CSR should prioritize the CSR fund to be used to fulfil the basic needs of the community. In the context of CSR fund awarded by tourism corporations, local communities should allocate it to cover the cost of empowering the human resources. Such empowerment would enable local communities to ameliorate their economic resources related to tourism industry. Tourism companies should identify the needs and the potency of local communities in their vicinity. The identification should be used as a basis to create sustainable programs that ensure the greater benefit to the community. In addition, they must establish means to indicate the achievement of their social programs. The government, both national and local levels, needs to step in and socialise CSR broadly and make sure that every tourism industry knows this programme really well. It is the responsibility of government to ensure that all stakeholders in the tourism industry will play a pivotal role to advance the CSR. 


\section{BIBLIOGRAPHY}

\section{Book}

Bowen, Howard R., Jean-Pascal Gond, and Peter Geoffrey Bowen, Social Responsibilities of the Businessman. University of Iowa Press, 2013.

Dharmayuda, I Made Suasthawa, Desa Adat Kesatuan Masyarakat Hukum Adat di Propinsi Bali. Upada Sastra Denpasar, 2001.

Gorda, I Gusti Ngurah, Manajemen Sumber Daya Manusia. Astabrata Bali in cooperation with STIE Satya Dharma, 2004.

Idowa, Samuel O., Abubaker S. Kasum, and Asli Yuksel Mermod, People, Planet and Profit: Socio-Economic Perspectives of CSR. Ashgate Publishing Ltd, 2014.

\section{Chapter in an Edited Book}

Astiti, Tjok Istri Putra, and I Ketut Sudantra, "Reflecting on Tourism Activities in Bali: A Discourse on Communal Rights, Culture and Hindu Values," in Sustainable Tourism and Law, edited by Michael G. Faure, Ni Ketut Supasti Dharmawan and I Made Budi Arsika (Den Haag: Eleven International Publishing, 2014).

\section{Journal Article}

Andrini, Laurensia. "Mandatory Corporate Social Responsibility in Indonesia." Mimbar Hukum-Fakultas Hukum Universitas Gadjah Mada 28, no. 3 (2016): 512-525.

Argandoña, Antonio. "Corporate Social Responsibility in the Tourism Industry: Some Lessons from the Spanish Experience”. IESE Business School Working Paper No. 844. (2010). http://dx.doi.org/10.2139/ssrn.1593592.

Bevan, Emma AM, and Ping Yung. "Implementation of Corporate Social Responsibility in Australian Construction SMEs." Engineering, Construction and Architectural Management 22, no. 3 (2015): 295-311. https://doi.org/10.1108/ECAM-05 $-2014-0071$

Del Baldo, Mara. "Sustainability and CSR Orientation through "Edutainment" in Tourism." International Journal of Corporate Social Responsibility 3, no. 5 (2018): 1-14. https://doi.org/10.1186/s40991-018-0027-2 
Greenberg, David. "Making Corporate Social Responsibility an Everyday Part of the Business of Business: Offering Realistic Options for Regulatory Reform." Bond L. Rev 19, no. 2 (2007).

Hamid, Md. Abdul. 2010, "CSR in Tourism", SSRN (2010). http://dx.doi. org/10.2139/ssrn.1684185

Hughes, Emma and Regina Scheyvens. "Corporate Social Responsibility in Tourism Post-2015: A Development First Approach.” Tourism Geographies 18 no.5 (2016): 469-482. https:// doi.org/10.1080/14616688.2016.1208678

Indrawati, Anak Agung Sri, Ni Ketut Supasti Dharmawan, and Ida Ayu Sukihana. "Implementasi Konsep CSR (Corporate Social Responsibility) Pada Perusahaan Industri Pariwisata di Bali." Kertha Patrika 37, no. 2 (2012).

Kasim, Azilah. "The Need for Business Environmental and Social Responsibility in the Tourism Industry." International Journal of Hospitality \& Tourism Administration 7, no. 1 (2006): 1-22. https://doi.org/10.1300/J149v07n01_01

Martinez, Patricia, Andrea Pérez, and Ignacio Rodríguez del Bosque. "Measuring Corporate Social Responsibility in Tourism: Development and Validation of an Efficient Measurement Scale in the Hospitality Industry." Journal of Travel \& Tourism Marketing 30, no.4 (2013): 365-385. https://doi.org/10.1080/1 0548408.2013 .784154

Nguyen, Minh, Jo Bensemann, and Stephen Kelly. "Corporate Social Responsibility (CSR) in Vietnam: A Conceptual Framework." International Journal of Corporate Social Responsibility 3, No. 9 (2018): 1-12. https://doi.org/10.1186/s40991018-0032-5

Roth, Dik, and Gede Sedana. "Reframing Tri Hita Karana: From 'Balinese Culture' to Politics." The Asia Pacific Journal of Anthropology 16, no. 2 (2015): 157175. https://doi.org/10.1080/14442213.2014.994674

Safa'at, Muchamad Ali. "Corporate Social Responsibility: A Constitutional Perspective," Jurnal Konstitusi 11, no. 1 (2014): 1-17.

Triari, Putri, Kali Jones, and Ni Gusti Ayu Dyah Satyawati. "Indigenous People, Economic Development and Sustainable Tourism: A Comparative Analysis between Bali, Indonesia and Australia". Udayana Journal of Law and Culture 1 no. 1 (2017): 16-30. https://doi.org/10.24843/UJLC.2017.v01.i01.p02 
Tribe, John. "The Concept of Tourism: Framing a Wide Tourism World and Broad Tourism Society." Tourism Recreation Research 24, no. 2 (1999): 75-81. https://doi.org/10.1080/02508281.1999.11014879

\section{Thesis}

Yanta, Viddi Dandi, "Implementasi Corporate Social Responsibility (CSR) Pada Perseroan Terbatas yang Bergerak dalam Bidang Pariwisata di Bali." Thesis, Magister of Notary Programme, Gadjah Mada University, 2009.

\section{Proceeding}

Truscott, Rachael A. (2007) "Corporate Social Responsibility in Australia: Constructing Reputation”. Proceedings 2007 Australia And New Zealand Marketing Academy Conference (ANZMAC), Dunedin, New Zealand.

\section{Legal Documents}

Australia, Acts Interpretation Act 1901 (Cth)

Australia, Corporations Act 2001 (Cth)

Indonesia, The 1945 Constitution of the Republic of Indonesia.

Indonesia, Act of Republic of Indonesia No. 25 Year 2007 concerning Investment

Indonesia, Act of Republic of Indonesia No. 40 Year 2007 concerning Limited Liability Company

Indonesia, Government Regulation of Republic of Indonesia No. 47 Year 2012 concerning Social and Environmental Responsibility of Limited Liability Company

Indonesia, Regulation of Head of Badung Regency No. 6 Year 2013 concerning Corporate Social Responsibility

United Nations World Tourism Organization, the Global Code of Ethics for Tourism

\section{Interview}

Artayasa, Wayan. "CSR: implementation" Interview by Authors. Puri Dalem Hotel, Sanur. December 8, 2015.

Dharmawan, Ni Ketut Supasti. "CSR in Tourism Industries." Interview by Authors, Faculty of Law, Udayana University, Denpasar, December 7, 2015. 


\section{Case Law}

Decision of Constitutional Court of the Republic of Indonesia No. 53/PUU$\mathrm{VI} / 2008$.

Decision of the Supreme Court of the Republic of Indonesia No. 148/Pid.Sus/2013/ PN.Tipikor.Smg

\section{Website Content}

Metro Bali. "Safari Peduli Pemeriksaan Mata dan Operasi Katarak untuk Lansia bersama John Fawcett Foundation," December 12, 2013. http://metrobali. com/safari-peduli-pecahkan-rekor-operasi-katarak-untuk-500-lansia/

Black, Leeora D. What We Do, Australian Centre for Corporate Social Responsibility, www.accsr.com.au

CSR Bali, Universal Children Day Celebration at Melia Bali Indonesia. December 3, 2014. http://www.csrbali.com/universal-children-day-celebration-at-meliabali-indonesia.htm .

Elkington, John, “Enter the Triple Bottom Linehttp://www.johnelkington.com/ archive/TBL-elkington-chapter.pdf

Ema Sukarelawanto, "ITDC Raih Super Platinum \& CSR Tri Hita Karana Award 2017," November 26, 2017. http://kabar24.bisnis.com/read/20171126/78/712684/ itdc-raih-super-platinum-csr-tri-hita-karana-award-2017

Human Rights Commission, "Corporate Social Responsibility and Human Rights (2008).” https://www.humanrights.gov.au/publications/corporate-socialresponsibility-human-rights

International Organisation for Standardisation, "ISO 26000 Guidance of Social Responsibility (2010)", http://www.iso.org/iso/home/standards/iso26000. htm

Jago, Leo, and Margaret Deery. "State of the Business Events Industry 2010," Report of Business Events Council of Australia, September 2011. http:/ /www. businesseventscouncil.org.au/files/State_of_the_Business_Events_Industry_ Report_2010.pdf 
Kabar Dewata. Tri Hita Karana CSR Awards Bagi Perusahaan yang Melakukan Tanggung Jawab Sosial". November 27, 2017. http://kabardewata.com/berita/ berita-utama/sosial/tri-hita-karana-csr-awards-bagi-perusahaan.html\#.WxVKHzSFNdg2017.

Liputan 6.Com, "Ini Dia 10 Destinasi Wisata yang Disebut Bali Baru”. February 27, 2016. https://www.liputan6.com/lifestyle/read/2445931/ini-dia-10-destinasiwisata-yang-disebut-bali-baru

Macquarie Dictionary Online. https://www.macquariedictionary.com.au

Small Business NSW Commissioner, What is CSR?, 2014. www.toolkit.smallbiz. nsw.gov.au

The Office of the UN High Commissioner for Human Rights, Guiding Principles on Business and Human Rights Implementing the United Nations "Protect, Respect and Remedy" Framework, United Nations, 2011.https://www.ohchr. org/Documents / Publications / GuidingPrinciplesBusinessHR_EN.pdf

Tourism Australia, www.tourism-australia.com

United Nations World Tourism Organization, "Corporate Social Responsibility Initiatives. http:/ / ethics.unwto.org/content/corporate-social-responsibility-initiatives

United Nations World Tourism Organization, "Private Sector Commitment to the UNWTO Global Code of Ethics for Tourism. http://ethics.unwto.org/content/ private-sector-commitment-unwto-global-code-ethics-tourism 